\title{
Episodic fluid flow in an active fault
}

\author{
Sarah Louis ${ }^{1}$, Elco Luijendijk ${ }^{1 *}$, István Dunkl ${ }^{1}$ and Mark Person ${ }^{2}$ \\ ${ }^{1}$ Geoscience Center, University of Göttingen, Goldschmidtstrasse 3, 37077 Göttingen, Germany \\ ${ }^{2}$ Department of Earth \& Environmental Science, New Mexico Institute of Mining and Technology, 810 Leroy Place, Socorro, \\ New Mexico 87801, USA
}

\begin{abstract}
We present a reconstruction of episodic fluid flow over the past $\sim 250 \mathrm{k} . \mathrm{y}$. along the Malpais normal fault, which hosts the Beowawe hydrothermal system (Nevada, USA), using a novel combination of the apatite $(\mathrm{U}-\mathrm{Th}) / \mathrm{He}(\mathrm{AHe})$ thermochronometer and a model of the thermal effects of fluid flow. Samples show partial resetting of the AHe thermochronometer in a 40-m-wide zone around the fault. Numerical models using current fluid temperatures and discharge rates indicate that fluid flow events lasting 2 k.y. or more lead to fully reset samples. Episodic fluid pulses lasting 1 k.y. result in partially reset samples, with 30-40 individual fluid pulses required to match the data. Episodic fluid flow is also supported by an overturned geothermal gradient in a borehole that crosses the fault, and by breaks in stable isotope trends in hydrothermal sinter deposits that coincide with two independently dated earthquakes in the past 20 k.y. This suggests a system where fluid flow is triggered by repeated seismic activity, and that seals itself over $\sim 1$ k.y. due to the formation of clays and silicates in the fault damage zone. Hydrothermal activity is younger than the 6-10 Ma age of the fault, which means that deep $(\sim 5 \mathrm{~km})$ fluid flow was initiated only after a large part of the $230 \mathrm{~m}$ of fault offset had taken place.
\end{abstract}

\section{INTRODUCTION}

Fault-hosted transient fluid flow and hydrothermal activity play an important role in a wide range of geologic processes, including metallogenesis (Weis et al., 2012), oil migration (Boles et al., 2004), fault mechanics, and metamorphism (Magee and Zoback, 1993). The time scale of fluid flow is important because the longer fluid flow is active, the more it changes subsurface temperatures and alters the rock matrix. Long-term changes in fluid flow and permeability in fault zones are driven by the competition between mineral precipitation (Lowell et al., 1993) and the creation of new flow paths by fault movement and the creation of connected fractures in fault damage zones (Sibson, 1981; Eichhubl et al., 2009). While field evidence of hydrothermal minerals precipitating in faults is common (Fisher et al., 2003; Eichhubl et al., 2009), the time scale at which new flow paths are opened by fault activity and closed by cementation is largely unknown (Woodcock et al., 2007). Data on changes in permeability or the duration

*E-mail: elco.luijendijk@geo.uni-goettingen.de of fluid flow in faults are rare, especially over geological time scales $\left(10^{4}-10^{7} \mathrm{yr}\right)$ (Ingebritsen and Gleeson, 2017).

Determining the duration of fluid flow in hydrothermal systems is often difficult because not all hydrothermal systems generate mineral deposits that can be dated, and because the uncertainty in dating hydrothermal minerals may exceed the duration of short hydrothermal events (Skinner, 1997). Several studies of fossil hydrothermal systems have demonstrated that low-temperature thermochronology offers new opportunities to date fluid flow by quantifying the thermal history of rocks in or adjacent to fluid conduits (Luijendijk, 2012; Gorynski et al., 2014; Hickey et al., 2014).

Here, we present a new approach to quantify the history of fluid flow in the active Beowawe hydrothermal system in the Basin and Range province (Nevada, United States), based on a combination of low-temperature thermochronology at high spatial resolution with a new model of conductive and advective heat flow (Luijendijk, 2019) that allows testing different hypotheses on the history of hydrothermal activity. Previous work suggests that fluid flow in the Beowawe system may have been episodic. Variations in trace elements in sinter and salinities in fluid inclusions indicate changes in fluid sources over time (Leatherman, 2010). ${ }^{14} \mathrm{C}$ ages and stable isotope data of hydrothermal sinter deposits show a change from a light to heavy $\delta^{18} \mathrm{O}$ signature that coincides with an independently dated earthquake along the Malpais fault at $7500 \mathrm{yr}$ B.P. (Howald et al., 2015). The most likely explanation is that the earthquake led to an increase in permeability, the opening of new flow paths, and the incorporation of a new isotopically heavy fluid source that is in equilibrium with a $5-\mathrm{km}$-deep carbonate formation (Howald et al., 2015). The ${ }^{14} \mathrm{C}$ and stable isotope record of fluid flow goes back $20 \mathrm{k}$.y. Our objective is to quantify the long-term ( $>20$ k.y.) history of hydrothermal activity.

\section{THE BEOWAWE HYDROTHERMAL SYSTEM}

The Beowawe hydrothermal system is located in north-central Nevada (Fig. 1A), southwest of the town of Elko. The area was once the second-most active geyser field in the United States, after Yellowstone National Park. However, in C.E. 1960, geyser activity ceased due to geothermal development (White, 1992). The geysers and hot springs were located in the hanging wall of the Malpais fault, an active normal fault that formed when extension rotated to a northwest-southeast direction at ca. 10-6 Ma (Zoback et al., 1981). The offset of the Malpais fault is $\sim 230 \mathrm{~m}$ (Fig. 1C). Alluvial sediments along the fault document vertical offsets of 0.7 and $2 \mathrm{~m}$ caused by earthquakes at 18,700 and $7500 \mathrm{yr}$ B.P., respectively (Wesnousky et al., 2005). Hydrothermal activity has generated a 1600-m-long sinter deposit at the footwall of the fault with a relatively constant thickness of $65 \mathrm{~m}$, consisting predominantly of opal (Zoback, 1979). The sinter terrace is underlain by middle Miocene 


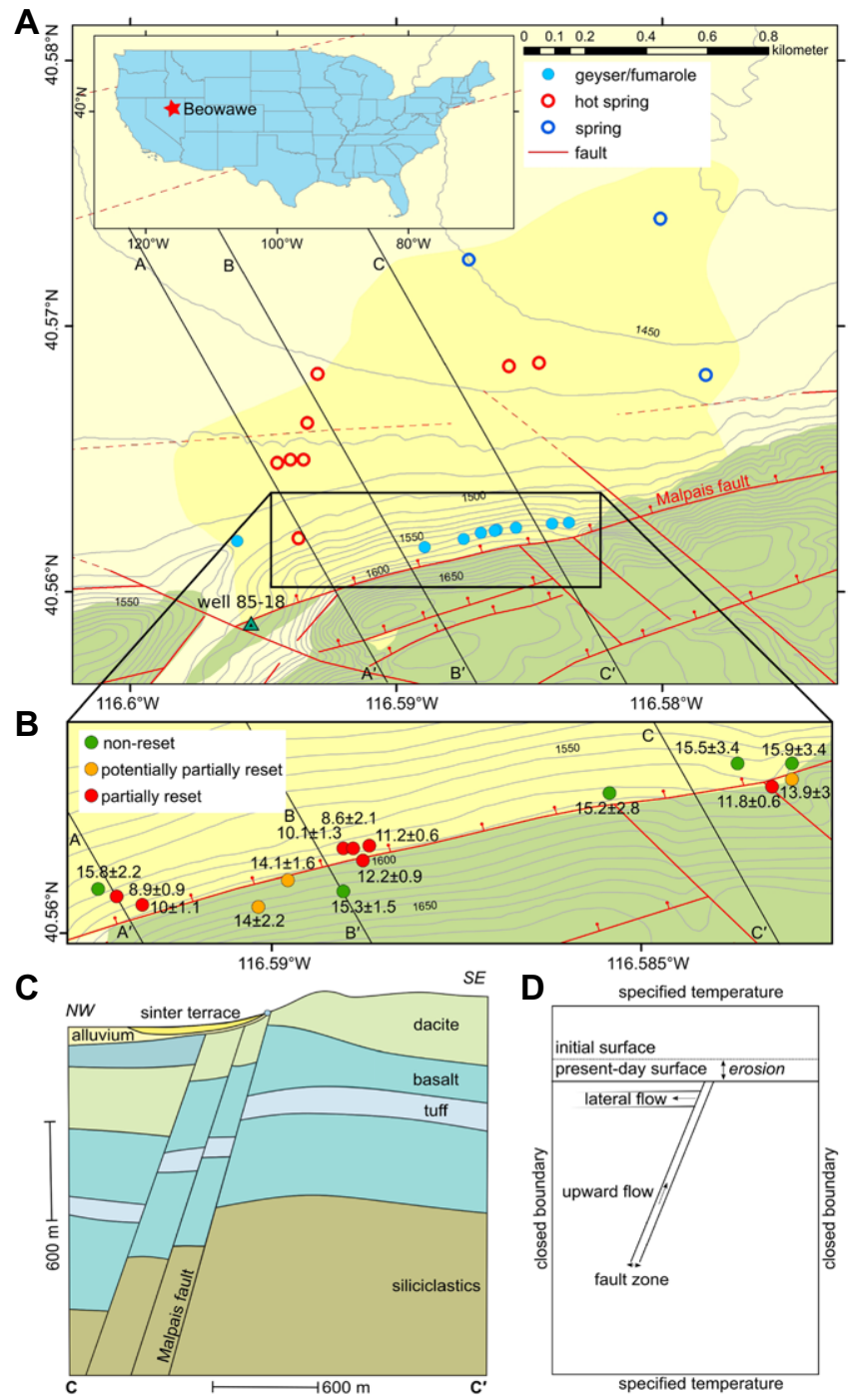

Figure 1. Geological map and cross section of hydrothermally active Malpais fault (Nevada, USA), sample locations, and measured apatite (U-Th)/He (AHe) ages. (A) Geological setting and locations of Chevron-U.S. Department of Energy exploratory well 85-18 (lovenitti and Epperson, 1981), three cross sections $A-A^{\prime}, B-B^{\prime}$, and $C-C^{\prime}$, and geysers and hot springs. Topographic contours denote meters above sea level, with an interval of $10 \mathrm{~m}$. (B) Close-up of the Malpais fault showing locations of surface samples and their average $\mathrm{AHe}$ ages (in Ma). Two samples are not shown: sample B4 because it did not yield apatite grains, and sample B17 because it was discarded due to abundant fluid inclusions. (C) Geological cross section perpendicular to the Malpais fault, modified after Hoang et al. (1987). (D) Framework and boundary conditions for the numerical model of conductive and advective heat flow that was used to interpret the AHe data set.

volcanic rocks, including dacite, basaltic andesite, and basalt, that overlie Ordovician sedimentary rocks (Struhsacker, 1980). Prior to 1960, the total fluid discharge was $0.018 \mathrm{~m}^{3} \mathrm{~s}^{-1}$, of which one-third discharged through the geysers and hot springs and two-thirds contributed to lateral discharge through alluvial sediments (Olmsted and Rush, 1987). The low salinity of hydrothermal fluids and their stable isotope composition point to a meteoric origin. The system is recharged at a topographic high northwest of the geysers and is driven by both topography and thermal convection (Olmsted and Rush, 1987; Howald et al., 2015). Low ${ }^{3} \mathrm{He} /{ }^{4} \mathrm{He}$ ratios suggest that there is no magmatic heat source (Banerjee et al., 2011). Geothermometers and ${ }^{13} \mathrm{C}$ concentration indicate that fluids were in contact with a carbonate reservoir at temperatures averaging $230{ }^{\circ} \mathrm{C}$ at a depth of $\sim 5 \mathrm{~km}$ (Rimstidt and Cole, 1983; Day, 1987; John et al., 2003).

\section{METHODS}

We collected 17 surface rock samples of middle Miocene dacites along the Malpais fault in calculate AHe ages. AHe ages equal crystallization age if the apatite grains have remained at low temperatures, but will tend toward zero if temperatures have exceeded $55-80{ }^{\circ} \mathrm{C}$ over long (thousands of years) time scales (Reiners et al., 2005). The model simulates only the part of the hydrothermal system where upward fluid flow and discharge take place. Flow starts at $5 \mathrm{~km}$ depth in a carbonate formation that is the likely origin of upward flow. The flow rate is imposed and is based on a reconstruction of the present-day fluid discharge at the surface and the flux along the fault (Olmsted and Rush, 1987). The temperature at the lower model boundary at $8 \mathrm{~km}$ depth was fixed at $330^{\circ} \mathrm{C}$, based on measured regional geothermal gradients (Zoback, 1979; Howald et al., 2015). We first quantified the age of the latest episode of fluid flow in this system by calibrating the model to a temperature record from Chevron-U.S. Department of Energy exploratory well 85-18 (Iovenitti and Epperson, 1981) near the western edge of the sinter terrace (Fig. 1A). We then ran models of continuous and episodic hydrothermal activity and compared modeled and measured AHe ages. Because hydrothermal activity may have varied temporally and spatially along the Malpais fault, the AHe samples were grouped along three profiles (Figs. 1A and 1B; Table 1). A number of different model experiments were conducted to test the effects of the duration of advective heating and thermal recovery on modeled $\mathrm{AHe}$ ages, with heating durations ranging from 0.5 to $2 \mathrm{k} . \mathrm{y}$. and thermal recovery ranging from 2 to 9.5 k.y.

\section{RESULTS}

Comparison of the modeled and measured borehole temperatures (Fig. 2G) constrains the age of the latest stage of the hydrothermal activity along the Malpais fault. The model results provide the best match to the observed temperatures for a fluid flow duration of 3 k.y. (Fig. 2) using flow rates that are based on reconstructions of fluid discharge along the fault (Olmsted and Rush, 1987). Longer run times would result in too much heating of the system and would also not reproduce the overturned geothermal gradient.

The large volume of hydrothermal sinter deposits indicates that the system must have been active much longer, 210 k.y. (Zoback, 1979). To quantify the long-term history of fluid flow, we used low-temperature thermochronology on surface samples close to the Malpais fault. The crystallization age of the volcanic host rock of the Beowawe hydrothermal system was dated using the zircon U-Pb method as 15.6 Ma (Table DR5 in the Data Repository). Samples at distances of $>40 \mathrm{~m}$ from the Malpais fault show $\mathrm{AHe}$ ages that are equal to the $\mathrm{U}-\mathrm{Pb}$ age (Fig. $1 \mathrm{~B})$, which signifies that they have not undergone heating of temperatures exceeding $\sim 55-80$ ${ }^{\circ} \mathrm{C}$ since their deposition in the Miocene. In contrast, most samples that are close to the Malpais 
TABLE 1. LOCATIONS AND MINIMUM, MAXIMUM AND AVERAGE SINGLE GRAIN AHE AGES FOR THE SURFACE OUTCROP SAMPLES USED IN THIS STUDY

\begin{tabular}{|c|c|c|c|c|c|c|c|c|}
\hline $\begin{array}{l}\text { Sample } \\
\text { ID }\end{array}$ & $\begin{array}{c}\text { Longitude } \\
\left.\text { (WGS84) ( }{ }^{\circ} \mathrm{W}\right)\end{array}$ & $\begin{array}{c}\text { Latitude } \\
\left(\text { WGS84) }\left({ }^{\circ} \mathrm{N}\right)\right.\end{array}$ & $\begin{array}{l}\text { Distance and direction } \\
\text { from fault }(\mathrm{m})\end{array}$ & $\begin{array}{l}\text { Cross- } \\
\text { section }\end{array}$ & $\begin{array}{l}\text { Minimum age } \\
(\text { m.y.) }\end{array}$ & $\begin{array}{l}\text { Maximum age } \\
\text { (m.y.) }\end{array}$ & $\begin{array}{l}\text { Average age } \\
\text { (m.y.) }\end{array}$ & $\begin{array}{l}\text { Average Error } \\
\text { (m.y.) }\end{array}$ \\
\hline $\mathrm{B} 1$ & 116.59235 & 40.5606 & $56 \mathrm{~N}$ & $A$ & 14.7 & 16.8 & 15.8 & 2.2 \\
\hline B2 & 116.5921 & 40.5605 & $40 \mathrm{~N}$ & A & 5.4 & 10.7 & 8.9 & 0.9 \\
\hline B3 & 116.59175 & 40.560384 & $15 \mathrm{~N}$ & $A$ & 8.1 & 10.9 & 10.0 & 1.1 \\
\hline B4 & 116.59018 & 40.561134 & $48 \mathrm{~N}$ & No data & & & & \\
\hline B5 & 116.58978 & 40.560717 & $7 \mathrm{~S}$ & B & 10.6 & 18.0 & 14.1 & 1.6 \\
\hline B6 & 116.5837 & 40.5623 & $35 \mathrm{~N}$ & $\mathrm{C}$ & 11.2 & 17.7 & 15.5 & 3.4 \\
\hline B7 & 116.58543 & 40.5619 & $18 \mathrm{~N}$ & $\mathrm{C}$ & 13.5 & 17.1 & 15.2 & 2.8 \\
\hline B8 & 116.58903 & 40.56115 & $20 \mathrm{~N}$ & B & 6.9 & 13.1 & 10.1 & 1.3 \\
\hline B9 & 116.5889 & 40.56115 & $17 \mathrm{~N}$ & $\mathrm{~B}$ & 4.2 & 13.4 & 8.6 & 2.1 \\
\hline B10 & 116.58868 & 40.561184 & $15 \mathrm{~N}$ & B & 10.1 & 12.7 & 11.2 & 0.6 \\
\hline B11 & 116.58323 & 40.561984 & $10 \mathrm{~S}$ & $\mathrm{C}$ & 10.5 & 12.8 & 11.8 & 0.6 \\
\hline B12 & 116.58296 & 40.562084 & $8 S$ & $\mathrm{C}$ & 7.7 & 17.8 & 13.9 & 3.0 \\
\hline B13 & 116.58876 & 40.560984 & $4 \mathrm{~S}$ & B & 11.3 & 14.0 & 12.2 & 0.9 \\
\hline B14 & 116.58903 & 40.560567 & $42 \mathrm{~S}$ & B & 11.8 & 17.4 & 15.3 & 1.5 \\
\hline B15 & 116.59014 & 40.560344 & $37 \mathrm{~S}$ & B & 12.4 & 17.0 & 14.0 & 2.2 \\
\hline B16 & 116.58296 & 40.5623 & $19 \mathrm{~N}$ & $\mathrm{C}$ & 11.4 & 19.7 & 15.9 & 3.4 \\
\hline B17 & 116.59615 & 40.561134 & $242 \mathrm{~N}$ & Discarded & & & & \\
\hline
\end{tabular}

Note: More details on the analysis and single grain ages can be found in Table DR5 (see text footnote 1).

fault show a small but consistent decrease in $\mathrm{AHe}$ ages that is likely the result of heating by hydrothermal fluids (Fig. 1B). The AHe data suggest that over long time scales, hydrothermal activity was focused on the Malpais fault. However, while fluid flow originated in the fault, historically the surface discharge was focused on a line of geysers on top of the sinter terrace, $\sim 70 \mathrm{~m}$ north of the fault (Fig. 1A). The focus of hydrothermal activity on the Malpais fault is consistent with the location of the oldest generation of sinter deposits that have been found close to the fault (White, 1998).

We quantified the duration of hydrothermal activity by comparing a model of advective and conductive heat flow to measured $\mathrm{AHe}$ ages along three profiles perpendicular to the fault (Fig. 1A). We first modeled the effects of

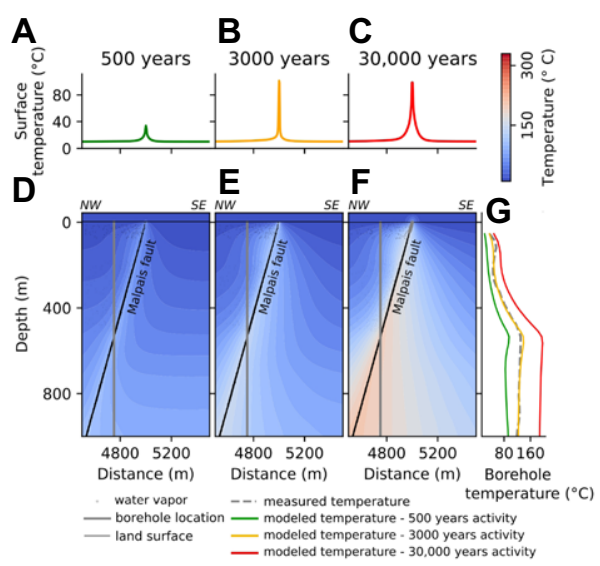

Figure 2. Comparison of modeled temperatures over time and borehole temperature record for Chevron-U.S. Department of Energy exploratory well 85-18 (lovenitti and Epperson, 1981) near Malpais fault (Nevada, USA), indicating that fluid flow in this section of the fault is $\sim 3$ k.y. old (panel G). (A-C) Surface temperature over time. (D-F) Modeled temperature field and location of borehole. G: Measured borehole temperature data and modeled temperatures for three time slices shown in panels A-C. Distance refers to the distance to the lefthand side of the model domain. continuous hydrothermal activity. The best fit suggests that hydrothermal activity lasted for $\sim 70$ k.y. for profiles B and C (Fig. 3A; Fig. DR9), and 290 k.y. for profile A (Fig. DR8), which is shorter than the $\sim 210 \mathrm{k} . \mathrm{y}$. that are required to deposit the volume of sinter present in the footwall of the fault at current fluid discharge rates and silica concentrations (Zoback, 1979). The results also indicate that the high fluid temperatures in the system would result in a full reset $(\mathrm{AHe}$ age $=0 \mathrm{Ma}$ ) of the AHe thermochronometer in a 13-m-wide zone around the fault, bounded by a 5 -m-wide zone with partially reset samples, for a duration of 70 k.y. For a duration of $200 \mathrm{k} . y$. ., the width of the zone with fully reset AHe ages would be $45 \mathrm{~m}$. However, even though the sampling was relatively dense, we did not find a single fully reset apatite (Fig. 1B; Table 1). This confirms that over longer time scales, hydrothermal activity was not continuous.

Model experiments of episodic hydrothermal activity show that periodic heating followed by thermal recovery results in only partially reset AHe ages around the fault and no fully reset samples (Fig. 3C). The best fit was obtained by 35 cycles of heating of $1 \mathrm{k} . \mathrm{y}$. each followed by 9 k.y. of thermal recovery (Figs. 3C and 3G; Fig. DR10). A model run with heating of 2 k.y. resulted in full resetting, whereas 500 yr was not sufficient to reduce AHe ages to their observed values (Fig. 3G; Fig. DR10C). This suggests that the individual fluid pulses lasted $>0.5 \mathrm{k}$.y. but $<2$ k.y. The duration of thermal recovery is not well constrained; a series of model runs showed that any value of $6.5 \mathrm{k} . \mathrm{y}$. or more provided a good fit (Fig. 3G; Fig. DR10C). This means that the hydrothermal system must have been at least 255 k.y. old.

Analysis of the model error (Fig. 3G; Fig. DR10) shows that the quantified duration of individual fluid pulses of $\sim 1$ k.y. is relatively insensitive to the inherent uncertainty of AHe data; model runs with shorter or longer fluid pulses show much higher model errors (Fig. 3G). However, the uncertainty of the total duration of fluid flow is affected by the uncertainty and dispersion of AHe ages and is estimated as \pm 80 k.y. The modeled effects of hydrothermal activity on AHe ages are strongly dependent on background exhumation rates. We assumed a background exhumation rate of $1 \times 10^{-4} \mathrm{~m} \mathrm{yr}^{-1}$, which is an average of reported regional values (see Section DR1.8 in the Data Repository). Sensitivity analysis (Fig. DR7) shows that halving the exhumation rate would double the modeled duration of hydrothermal activity.

\section{DISCUSSION AND CONCLUSIONS}

The much better fit of episodic fluid flow models to the AHe data (Fig. 3C) compared to models of continuous fluid flow means that either fluid flow in the Beowawe system ceased between the 1-k.y.-long fluid pulses or that overall fluid flow in the Beowawe system was continuous but shifted location every $\sim 1$ k.y. The latter explanation is favored by the distribution of ${ }^{14} \mathrm{C}$ ages of hydrothermal sinter deposits (Howald et al., 2015), which suggests relatively constant fluid discharge over the past $20 \mathrm{k} . \mathrm{y}$.

The $1 \mathrm{k} . \mathrm{y}$. length of fluid pulses suggested by the AHe data is shorter than the $3 \mathrm{k} . \mathrm{y}$. age of the latest fluid pulse based on modeled borehole temperatures. The difference may be resolved if one assumes higher flow rates at the start of the last fluid pulse and decaying permeability and flow rates over time instead of constant rates. This would have increased subsurface temperatures and reduce the reconstructed age of the last fluid pulse. At shallow levels, temperatures are limited by the boiling temperature, and higher flow rates would therefore not have affected AHe ages and the reconstructed duration of fluid pulses of $1 \mathrm{k} . \mathrm{y}$.

The reconstructed start of hydrothermal activity of $\sim 250 \mathrm{k}$.y. is much younger than the 10-6 Ma age of tectonic activity of the Malpais fault. One explanation for the relatively recent appearance of the Beowawe hydrothermal system may be that continuous fault movement has gradually increased permeability of the fault damage zone, and permeability and fracture 


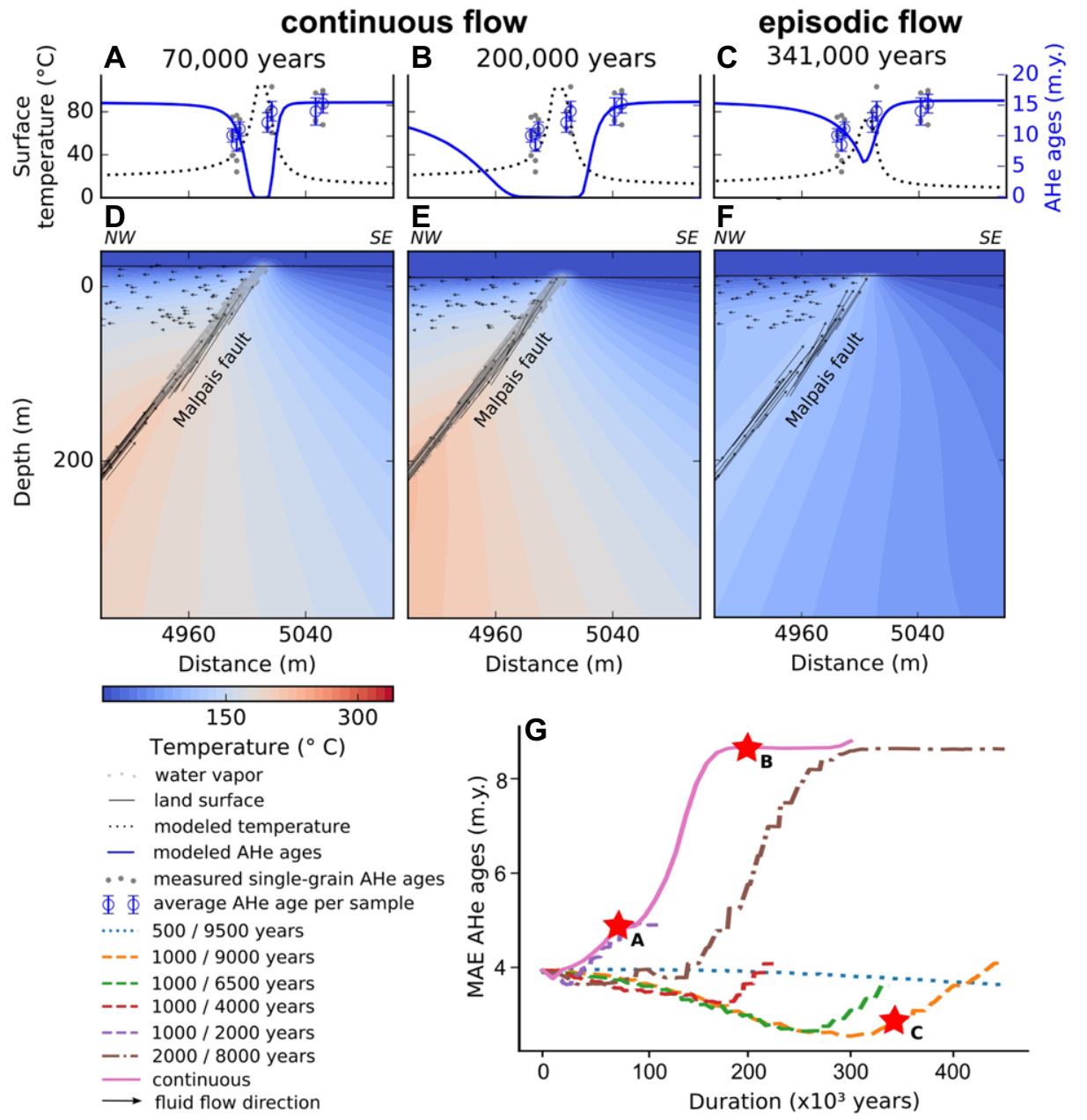

Figure 3. Modeled temperatures over long (thousands of years) time scales around Malpais fault (Nevada, USA) and comparison with measured apatite (U-Th)/He (AHe) samples for a continuous flow lasting 70 k.y. (A,D) and 200 k.y. (B,E), and 35 cycles of episodic flow with each cycle consisting of $1 \mathrm{k} . \mathrm{y}$. of fluid flow followed by 9 k.y. of thermal recovery (C,F). Panels A-C show comparison between observed and modeled AHe ages for rocks at the surface. Error bars represent the $\pm \mathbf{2}$ standard error of the AHe age. Panels $D-F$ show modeled temperatures in the slice of model domain around Malpais fault. Panel G depicts mean absolute error (MAE) of modeled and measured single-grain AHe ages for several model experiments of continuous and episodic hydrothermal activity. Results are shown for profile B-B' (see Fig. 1 for location), which had the highest density of AHe data. "1000/9000" denotes $1000 \mathrm{yr}$ of fluid flow followed by 9000 yr of thermal recovery. Red stars show model error of model outputs shown in panels $A, B$, and $C$. Distance refers to the distance to the left-hand side of the model domain.

connectivity reached a threshold value that was sufficient to channel fluids along the fault from $\sim 5 \mathrm{~km}$ depth $250 \mathrm{k} . \mathrm{y}$. ago. The formation of connected pathways in the fault damage zone would have been slowed by the formation of a clay-rich alteration zone with low permeability (Cole and Ravinsky, 1984), and by the sealing of the fault zone with silica precipitated by hydrothermal fluids.

Although the stable isotope record of Howald et al. (2015) provides a clear indication of the effects of earthquakes on opening new flow paths, not all changes in fluid flow can be attributed to earthquakes. Comparison of the modeled heat flow and the temperature record of well 85-18 provides evidence for the opening of a new flow path along the Malpais fault $\sim 3$ k.y. ago (Fig. 2 ), whereas the latest earthquake was dated as
7500 yr B.P. (Wesnousky et al., 2005). One explanation may be simply that there has been a more recent earthquake on the Malpais fault that has not been detected by paleoseismic investigations. Alternatively, new flow paths may have been opened by permeability changes induced by earthquakes in nearby faults and the resulting changes in stress (Caskey and Wesnousky, 2000).

\section{ACKNOWLEDGMENTS}

Louis and Luijendijk gratefully acknowledge support by postdoctoral startup funding (grant number 3917542) by the University of Göttingen, Germany. Support to Person by the W.M. Keck foundation (Los Angeles, California; grant 989941) is gratefully acknowledged. We also thank Volker Karius for the X-ray diffraction measurements, and Jonas Kley and David Hindle for helpful comments on an early version of the manuscript. The manuscript benefited from comments by Peter Reiners and three anonymous reviewers.
REFERENCES CITED

Banerjee, A., et al., 2011, Deep permeable fault-controlled helium transport and limited mantle flux in two extensional geothermal systems in the Great Basin, United States: Geology, v. 39, p. 195-198, https://doi.org/10.1130/G31557.1.

Boles, J.R., Eichhubl, P., Garven, G., and Chen, J., 2004 , Evolution of a hydrocarbon migration pathway along basin-bounding faults: Evidence from fault cement: American Association of Petroleum Geologists Bulletin, v. 88, p. 947-970, https://doi .org/10.1306/02090403040.

Caskey, S.J., and Wesnousky, S.G., 2000, Active faulting and stress redistributions in the Dixie Valley, Beowawe, and Bradys geothermal fields: Implications for geothermal exploration in the Basin and Range, in Proceedings, Twenty-Fifth Workshop on Geothermal Reservoir Engineering, Stanford, California, 24-26 January.

Cole, D.R., and Ravinsky, L.I., 1984, Hydrothermal alteration zoning in the Beowawe geothermal system, Eureka and Lander Counties, Nevada: Economic Geology and the Bulletin of the Society of Economic Geologists, v. 79, p. 759-767, https:// doi.org/10.2113/gsecongeo.79.4.759.

Day, G.A., 1987, Source of recharge to the Beowawe geothermal system, north-central Nevada [M.S. thesis]: Reno, University of Nevada, Reno, $82 \mathrm{p}$.

Eichhubl, P., Davatz, N.C., and Becker, S.P., 2009, Structural and diagenetic control of fluid migration and cementation along the Moab fault, Utah: American Association of Petroleum Geologists Bulletin, v. 93, p. 653-681, https://doi. org/10.1306/02180908080.

Fisher, Q.J., Casey, M., Harris, S.D., and Knipe, R.J., 2003, Fluid-flow properties of faults in sandstone: The importance of temperature history: Geology, v. 31, p. 965-968, https://doi.org/10.1130/G19823.1.

Gorynski, K.E., Walker, J.D., Stockli, D.F., and Sabin, A., 2014, Apatite (U-Th)/He thermochronometry as an innovative geothermal exploration tool: A case study from the southern Wassuk Range, Nevada: Journal of Volcanology and Geothermal Research, v. 270, p. 99-114, https://doi .org/10.1016/j.jvolgeores.2013.11.018.

Gross, L., Bourgouin, L., Hale, A.J., and Mühlhaus, H.-B., 2007a, Interface modeling in incompressible media using level sets in Escript: Physics of the Earth and Planetary Interiors, v. 163, p. 2334, https://doi.org/10.1016/j.pepi.2007.04.004.

Gross, L., Cumming, B., Steube, K., and Weatherley, D., 2007b, A Python module for PDE-based numerical modelling, in Kågström, B., et al., eds., Applied Parallel Computing: State of the Art in Scientific Computing: $8^{\text {th }}$ International Workshop, PARA 2006, Umeå, Sweden, June 18-21, 2006, Revised Selected Papers: Berlin, Springer, Lecture Notes in Computer Science, v. 4699, p. 270-279, https://doi.org/10.1007/978-3-540-75755-9_33.

Hickey, K.A., Barker, S.L.L., Dipple, G.M., Arehart, G.B., and Donelick, R.A., 2014, The brevity of hydrothermal fluid flow revealed by thermal halos around giant gold deposits: Implications for Carlin-type gold systems: Economic Geology and the Bulletin of the Society of Economic Geologists, v. 109 , p. 1461-1487, https://doi.org/10.2113/ econgeo.109.5.1461.

Hoang, V.T., James, E.D., and Epperson, I.J., 1987, Development Drilling, Testing and Initial Production of the Beowawe Geothermal Field: Proceedings of the Twelfth Workshop on Geothermal Reservoir Engineering, Stanford, California, January 20-22, p. 159-162.

Howald, T., et al., 2015, Evidence for long timescale $\left(>10^{3}\right.$ years) changes in hydrothermal activity induced by seismic events: Geofluids, v. 15, p. 252-268, https://doi.org/10.1111/gfl.12113. 
Ingebritsen, S.E., and Gleeson, T., 2017, Crustal permeability: Hydrogeology Journal, v. 25, p. 2221-2224, https://doi.org/10.1007/s10040017-1663-4.

Iovenitti, J.L., and Epperson, I.J., Jr., 1981, Beowawe geothermal area evaluation program: Final report: San Francisco, Chevron Resources Company, (prepared for the U.S. Department of Energy, Division of Geothermal Energy, under contract DE-AC08-78ET-27101), https://digital.library. unt.edu/ark:/67531/metadc1207149/m2/1/high_ res_d/6509007.pdf.

John, D.A., Hofstra, A.H., Fleck, R.J., Brummer, J.E., and Saderholm, E.C., 2003, Geologic setting and genesis of the Mule Canyon low-sulfidation epithermal gold-silver deposit, north-central Nevada: Economic Geology and the Bulletin of the Society of Economic Geologists, v. 98, p. 425-463, https://doi.org/10.2113/gsecongeo.98.2.425.

Leatherman, M., 2010, Geochemistry and reaction path modelling of the Beowawe hydrothermal system, Nevada: A barren end-member epithermal system [M.S. thesis]: Columbia, University of Missouri-Columbia, $122 \mathrm{p}$.

Lowell, R.P., Van Cappellen, P., and Germanovich, L.N., 1993, Silica precipitation in fractures and the evolution of permeability in hydrothermal upflow zones: Science, v. 260, p. 192-194, https:// doi.org/10.1126/science.260.5105.192.

Luijendijk, E., 2012, The role of fluid flow in the thermal history of sedimentary basins: Inferences from thermochronology and numerical modeling in the Roer Valley Graben, southern Netherlands [Ph.D. thesis]: Amsterdam, Vrije Universiteit Amsterdam, 198 p.

Luijendijk, E., 2019, ElcoLuijendijk/beo: Beo v1.0.1: Zenodo, https://doi.org/10.5281/zenodo. 2601328 .

Magee, M.E., and Zoback, M.D., 1993, Evidence for a weak interplate thrust fault along the northern Japan subduction zone and implications for the mechanics of thrust faulting and fluid expul- sion: Geology, v. 21, p. 809-812, https://doi .org/10.1130/0091-7613(1993)021<0809:EFA WIT>2.3.CO;2.

Meesters, A.G.C.A., and Dunai, T.J., 2002a, Solving the production-diffusion equation for finite diffusion domains of various shapes: Part I. Implications for low-temperature (U-Th)/He thermochronology: Chemical Geology, v. 186, p. 333-344, https://doi.org/10.1016/S0009-2541(01)00422-3.

Meesters, A.G.C.A., and Dunai, T.J., 2002b, Solving the production-diffusion equation for finite diffusion domains of various shapes: Part II. Application to cases with $\alpha$-ejection and nonhomogeneous distribution of the source: Chemical Geology, v. 186, p. 57-73, https://doi .org/10.1016/S0009-2541(01)00423-5.

Olmsted, F.H., and Rush, F.E., 1987, Hydrogeologic reconnaissance of the Beowawe Geysers geothermal area, Nevada: Geothermics, v. 16, p. 27-46, https://doi.org/10.1016/0375-6505(87)90077-0.

Reiners, P.W., Ehlers, T.A., and Zeitler, P.K., 2005, Past, present, and future of thermochronology: Reviews in Mineralogy and Geochemistry, v. 58, p. 1-18, https://doi.org/10.2138/rmg.2005.58.1.

Rimstidt, J.D., and Cole, D.R., 1983, Geothermal mineralization: I, The mechanism of formation of the Beowawe, Nevada, siliceous sinter deposit: American Journal of Science, v. 283, p. 861-875, https://doi.org/10.2475/ajs.283.8.861.

Sibson, R.H., 1981, Fluid flow accompanying faulting: Field evidence and models, in Simpson, D.W., and Richards, P.G., eds., Earthquake Prediction: An International Review: American Geophysical Union Maurice Ewing Series 4, p. 593-603, https://doi.org/10.1029/ME004p0593.

Skinner, B.J., 1997, Hydrothermal mineral deposits: What we do and don't know, in Barnes, H.L. ed., Geochemistry of Hydrothermal Ore Deposits (third edition): New York, John Wiley \& Sons Inc., p. 1-30.

Struhsacker, E.M., 1980, The geology of the Beowawe geothermal system, Eureka and Lander
Counties, Nevada: Salt Lake City, University of Utah Research Institute, Earth Science Laboratory, prepared for the U.S. Department of Energy, Division of Geothermal Energy, under contract DOE/ID/12079, 78 p., https://doi .org/10.2172/6718905.

Weis, P., Driesner, T., and Heinrich, C.A., 2012, Porphyry-copper ore shells form at stable pressure-temperature fronts within dynamic fluid plumes: Science, v. 338, p. 1613-1616, https:// doi.org/10.1126/science.1225009.

Wesnousky, S.G., Barron, A.D., Briggs, R.W., Caskey, S.J., Kumar, S., and Owen, L., 2005, Paleoseismic transect across the northern Great Basin: Journal of Geophysical Research, v. 110, B05408, https://doi.org/10.1029/2004JB003283.

White, D.E., 1992, The Beowawe Geysers, Nevada, before geothermal development: U.S. Geological Survey Bulletin 1998, 25 p., https://doi .org/10.3133/b1998.

Woodcock, N.H., Dickson, J.A.D., and Tarasewicz, J.P.T., 2007, Transient permeability and reseal hardening in fault zones: Evidence from dilation breccia textures, in Lonergan, L., et al., eds., Fractured Reservoirs: Geological Society of London Special Publication 270, p. 43-53, https://doi .org/10.1144/GSL.SP.2007.270.01.03.

Zoback, M.L.C., 1979, Geologic and geophysical investigation of the Beowawe geothermal area, north-central Nevada: Stanford, California, Stanford University, Publications in the Geological Sciences, v. 16, 79 p.

Zoback, M.L., Anderson, R.E., and Thompson, G.A., 1981, Cainozoic evolution of the state of stress and style of tectonism of the Basin and Range province of the western United States: Philosophical Transactions of the Royal Society of London, Series A: Mathematical and Physical Sciences, v. 300, p. 407-434, https://doi.org/10.1098/rsta.1981.0073.

Printed in USA 